\title{
Modul Berbasis Pendekatan Saintifik Dalam Pembelajaran Pendidikan Jasmani Olahraga Dan Kesehatan
}

\author{
Wahyu Hananingsih', Ali Imran ${ }^{2}$ \\ Universitas Islam Negeri (UIN) Mataram \\ Email: wahyuhananingsih@uinmataram.ac.id
}

\begin{abstract}
Abstrak. Pembelajaran pendidikan jasmani tidak dapat berjalan dengan baik jika tidak adanya guru, kurikulum, metode dan sarana prasarana yang dapat mendukung terlaksananya pembelajaran tersebut. Keberhasilan pembelajaran sangat ditentukan oleh beberapa factor yaitu salah satunya adalah guru yang secara langsung dapat berperan dalam tercapainya tujuan pendidikan di sekolah. Di masa covid 19 ini, tentunya pembelajaran tidak bisa dilaksanakan sebagaimana mestinya. Salah satu model pembelajaran yang tepat digunakan dalam pembelajaran pendidikan jasmani dan kesehatan pada masa saat ini yaitu dengan menerapkan model pembelajaran saintifik. Pada dasarnya model pembelajaran ini bukanlah hal yang baru, akan tetapi model pembelajaran menggunakan pendekatan ini jarang dilakukan oleh para guru pendidikan jasmani olahraga dan Kesehatan. Model pembelajaran saintifik ini memiliki ciri-ciri umum dalam kegiatan pembelajaran yaitu lebih mengedepankan proses pembelajaran dari pada hasilnya. Secara terminology pembelajaran dengan pendekatan saintifik adalah pembelajaran yang terdiri atas kegiatan yaitu dengan mengamati (untuk mengidentifikasi hal-

hal yang ingin diketahui), merumuskan kegiatan pertanyaan, mencoba atau mengumpulkan informa si dengan berbagai teknik, mengasosiasi atau menganalisis informasi dan menarik kesimpulan serta mengomunikasikan hasil yang terdiri dari kesimpulan untuk memperoleh pengetahuan, keterampilan dan sikap. Model pembelajaran berbasis pendekatan ilmiah, jika dilakukan dengan kaidah- kaidah yang benar, maka akan menciptakan siswa yang kreatif, inovatif, dan berpikir kritis serta peserta didik dapat belajar secara mandiri. Pada masa covid-19 ini, modul dengan model pendekatan saintifik sangatlah efektif digunakan sebagai pedoman dalam pelaksanaan pembelajaran pendidikan jasmani olahraga dan Kesehatan.
\end{abstract}

\section{Kata Kunci: Modul, Pendekatan Saintifik, dan Pendidikan Jasmani Olahraga dan Kesehatan}

\section{PENDAHULUAN}

Pendidikan jasmani olahraga dan Kesehatan merupakan mata pelajaran yang ada dalam jenjang pendidikan dasar, pendidikan menengah dan perguruan tinggi dalam jurusan tertentu. Pengertian dari pendidikan jasmani olahraga dan Kesehatan adalah suatu proses pembelajaran melalui aktivitas gerak yang bertujuan untuk menigkatkan kebugaran jasmani, mengembangkan keterampilan gerak dan juga untuk mengembangkan karakter siswa. Dalam Undang-Undang Republik Indonesia No 20 Tahun 2003 tentang Sistem Pendidikan dijelaskan terkait pengertian dari pendidikan dan tujuan pendidikan itu sendiri. Pengertian Pendidikan dalam Undang-Undang No 20 Tahun 2003 yaitu usaha sadar dan terencana untuk mewujudkan suasana belajar dan proses pembelajaran agar peserta didik secara aktif mengembangkan potensi dirinya untuk memiliki kekuatan spiritual keagamaan, pengendalian diri, kepribadian, kecerdasan, akhlak mulia, serta keterampilan yang diperlukan dirinya, masyarakat, bangsa dan negara. Sedangkan tujuannya adalah untuk berkembangnya potensi peserta didik agar menjadi manusia yang beriman dan bertakwa kepada Tuhan Yang Maha Esa, berakhlak mulia, sehat, berilmu, cakap, kreatif, mandiri, dan menjadi warga negara yang demokratis serta bertanggung jawab. Jika dilihat dari pengertian dan tujuan tersebut sangatlah sejalan dengan apa yang menjadi cita-cita seorang guru, akan tetapi melihat kondisi saat ini menggunakan pembelajaran daring yang perlu dipikirkan yaitu bagaimana cara untuk mencapai tujuan tersebut.

Guru merupakan komponen paling menentukan dalam sitem pendidikan secara keseluruhan, yang harus mendapat perhatian 
sentral, pertama, dan utama. Dalam pandangan Rusman,dkk (2011), guru merupakan penentu yang sangat dominan dalam pendidikan pada umumnya, karena guru memegang peranan dalam proses pembelajaran dimana proses pembelajaran merupakan inti dari proses pendidikan secara keseluruhan. Tugas guru adalah merencanakan pembelajaran sebaikbaiknya. Proses pembelajaran dalam kurikulum 2013 menggunakan pendekatan saintifik. Hal ini dimaksudkan untuk memberikan pemahaman kepada peserta didik dalam mengenal, memahami berbagai materi menggunakan pendekatan ilmiah, bahwa informasi bisa berasal dari mana saja, kapan saja, tidak bergantung pada informasi searah dari guru (Majid, 2014). Pembelajaran dengan pendekatan saintifik adalah pembelajaran yang memberikan kesempatan kepada peserta didik untuk mendapat pengalaman belajar melalui mengamati, menanya, mengumpulkan informasi, mengasosiasi dan mengkomunikasikan (Daryanto dan Saiful, 2017). Pembelajaran menggunakan pendekatan saintifik akan berpusat pada siswa atau peserta didik, Guru atau pendidik harus dapat mendesain referensi sebaik mungkin agar mudah dipahami dan dilaksanakan oleh peserta didik.

\section{PEMBAHASAN}

\section{APA ITU MODUL}

Modul adalah bagian kesatuan belajar yang terencana yang dirancang untuk membantu siswa secara individual dalam mencapai tujuan belajarnya (Sukiman, 2011). Selain itu Prastowo, A (2012) menyatakan modul merupakan bahan ajar yang disusun secara sistematis dengan bahasa yang mudah dipahami oleh siswa sesuai usia dan tingkat pengetahuan mereka agar mereka dapat belajar secara mandiri dengan bimbingan minimal dari pendidik.

Berdasarkan kedua pendapat diatas dapat disimpulkan bahwa modul merupakan bahan belajar mandiri yang dapat membantu peserta didik menguasai tujuan belajarnya dengan program yang disusun dan didesain sedemikian rupa sebagai bahan belajar mandiri untuk membantu peserta didik mencapai tujuannya. Ada empat komponen yang harus ada di dalam sebuah modul yaitu petunjuk penggunaan, program kegiatan siswa, lembar kerja dan alat evaluasi. Modul dapat dikatakan baik dan menarik apabila memiliki karakteristik tertentu. Karakteristik sebuah modul yang dimaksud yaitu self instruction, self contained, stad alone, adaptif, dan userfriendly (Direktorat Pembinaan, 2008)

1. Self Intruction adalah siswa dimungkinkan belajar secara mandiri dan tidak tergantung pada pihak lain.

2. Self Contained, seluruh materi pembelajaran yang dibutuhkan termuat dalam modul tersebut. Karakteristik ini memberikan kesempatan kepada siswa untuk mempelajari materi pembelajaran secara tuntas.

3. Stand Alone, modul yang dikembangkan tidak tergantung pada bahan ajar lain atau tidak harus digunakan bersama-sama dengan bahan ajar lain. Siswa tidak perlu bahan ajar lain untuk mempelajari atau mengerjakan tugas pada modul tersebut.

4. Adaptif, modul tersebut dapat menyesuaikan perkembangan ilmu pengetahuan dan teknologi, fleksibel/luwes digunakan diberbagai perangkat keras (hardware). Modul yang adaptif adalah jika modul tersebut dapat digunakan sampai kurun waktu tertentu.

5. User Friendly (bersahabat/akrab), modul memiliki instruksi dan paparan informasi bersifat sederhana, mudah dimengerti, serta menggunakan istilah yang umum digunakan. Penggunaan bahasa sederhana dan penggunaaan istilah yang umum digunakan merupakan salah satu bentuk user friendly.

Adapun tujuan pembuatan modul yatu: dapat belajar dengan kesanggupan dan menurut lamanya waktu yang digunakan mereka masing-masing, dapat belajar sesuai dengan cara dan teknik mereka masingmasing, memberikan peluang yang luas untuk memperbaiki kesalahan dan remedial serta banyaknya ulangan dan dapat belajar sesuai dengan topik yang diminati.

Modul juga tentunya memiliki penilaian khusus agar nantinya dapat menghasilkan modul yang berkualitas. Menurut Depdiknas 
(2008) menyatakan komponen evaluasi dari sebuah modul terdiri dari:

1. Komponen kelayakan isi mencakup, antara lain: kesesuaian dengan $\mathrm{SK}, \mathrm{KD}$; kesesuaian dengan perkembangan anak; kesesuaian dengan kebutuhan bahan ajar; kebenaran substansi materi pembelajaran; manfaat untuk penambahan wawasan; kesesuaian dengan nilai moral, dan nilainilai sosial.

2. Komponen kebahasaan antara lain mencakup: keterbacaan; kejelasan informasi; kesesuaian dengan kaidah bahasa Indonesia yang baik dan benar; pemanfaatan bahasa secara efektif dan efisien (jelas dan singkat);

3. Komponen penyajian antara lain mencakup: kejelasan tujuan (indikator) yang ingin dicapai; urutan sajian; pemberian motivasi, daya tarik; interaksi (pemberian stimulus dan respond); kelengkapan informasi

4. Komponen kegrafikan antara lain mencakup: penggunaan font; jenis dan ukuran; lay out atau tata letak; ilustrasi, gambar, foto; desain tampilan

Sistematika dalam menulis sebuah modul juga sangat penting diperhatikan, karena dengan adanya sitematika tersebut seorang guru atau pendidik akan mudah menulis dengan baik dan dapat menentukan target capaiannya. Adapun sistematika penulisan modul dapat diurutkan sebagai berikut: judul modul, petunjuk penggunaan modul, tujuan yang diharapkan setelah mempelajari modul, pengantar modul, unit 1, uraian materi, penugasan, tujuan, media atau alat, langkahlangkah pembelajaran, penilaian, rangkuman, latihan soal, kunci jawaban, kriteria pindah atau lulus modul dan daftar pustaka.

\section{MODEL SAINTIFIK \\ PEMBELAJARAN}

Pembelajaran merupakan suatu proses ilmiah yang dilalui oleh setiap siswa atau peserta didik. Kurikulum 2013 mengamanatkan pendekatan ilmiah dalam pembelajaran seperti pendekatan saintifik. Menurut kamus besar Bahasa Indonesia (2011) edisi kedua, pendekatan adalah proses perbuatan, cara mendekati atau usaha dalam rangka aktivitas penelitian untuk mengadakan hubungan dengan orang yang diteliti. Sedangkan saintifik secara etimologi berasal dari kata sains yang berarti pengetahuan sistematis yang diperoleh dari suatu observasi, penelitian dan uji coba yang mengarah pada penentuan sifat dasar atau prinsip sesuatu yang sedang diteliti atau dipelajari Adapun pendapat lain mengatakan pendekatan saintifik adalah pembelajaran yang memeberi kesempatan kepada peserta didik untuk mendapatkan pengalaman belajar melalui mengamati, menanya, mengumpulkan informasi, mengasosiasi dan mengomunikasikan. (Daryanto dan Syaiful,2017). Dari kedua pendapat di atas dapat disimpulkan bahwa pendekatan saintifik adalah proses memperoleh pengetahuan yang sistematis tentang sesuatu yang sedang dipelajari melalui tahapan-tahapan ilmiah. Proses pembelajaran disbut ilmiah jika memenuhi kriteria yaitu substansi dan materi pembelajaran berbasis fakta atau fenomena yang dapat dijelaskan dengan logika atau penalaran tertentu dan proses pembelajaran harus terhindar dari sifatsifat nilai-nilai non ilmiah, prasangka dan melalui coba-coba.

Pendekatan saintifik merupakan konsep dasar yang mewadahi, menginspirasi, menguatkan dan mendasari pemikiran tentang bagaimana metode pembelajaran diterapkan berdasarkan teori tertentu.. Selain itu, proses pembelajarannya mengimplementasikan pendekatan saintifik yang terkait dengan tiga ranah yaitu sikap (afektif), pengetahuan (kognitif) dan keterampilan (psikomotor)

Prinsip pembelajaran dalam pendekatan saintifik adalah memperhatikan anak belajar dari kenyataan. Dengan seperti itu anak tertarik untuk terlibat langsung dalam pengamatan serta dilandasi rasa senang. Selain itu ada juga prinsip yang harus diperhatikan untuk menguatkan pembelajaran yaitu anak belajar secara nyata dalam arti melalui pengamatan gambar ataupun media audio visual sudah dapat memahami pelaksanaannya, belajar dengan cara berbuat, dan belajar dilandasi perasaan senang serta tidak membosankan, ini terkait dengan bagaiamana seorang guru dapat mendesain 
gambar yang sesuai dengan langkah-langkah pelaksanaan, menarik dan mudah dipahami.

Terdapat beberapa karakteristik dalam pembelajaran saintifik yaitu pembelajaran berpusat pada siswa atau peserta didik, melibatkan proses kognitif yang potensial dalam merangsang perkembangan intelek, mengembangkan karakter siswa atau peserta didik dan melibatkan keterampilan yang dimilikinya berdasarkan pengamatan.

Model pembelajaran ini juga memiliki beberapa tujuan yaitu siswa atau peserta didik memahami langkah-langkah pembelajaran ilmiah, untuk meningkatkan kemampuan berpikir peserta didik, terciptanya kondisi pembelajaran yang membuat peserta didik merasa bahwa belajar itu merupakan suatu kebutuhan, mengasah kemampuan sikap, pengetahuan dan keterampilan melalui metode yang tepat

Langkah-langkah

penerapan pembelajaran saintifik dalam pembelajaran pendidikan jasmani olaharaga dan kesehatan sebagai berikut:

1) Mengamati (Observasi)

Metode mengamati merupakan langkah pertama dalam kegiatan pembelajaran pendidikan jasmani olahraga dan Kesehatan, Metode mengamati sangat bermanfaat bagi pemenuhan rasa ingin tahu siswa. Mengamati dalam pembelajaran ini memiliki arti bahwa siswa atau peserta didik diajak untuk meliahat gambar melalui audio visual atapun gambar pada modul yang tentunya diharapkan guru atau pendidik dapat merancang sebaik mungkin agar mudah dipahami.

2) Menanya

Tahap selanjutnya adalah menanya, menanya adalah mengungkapkan bahwa guru yang efektif mampu menginspirasi siswa untuk meningkatkan dan mengembangkan ranah sikap, keterampilan, dan pengetahuannya. Maksud dari kegiatan ini adalah untuk mempermudah siswa mengetahui tentang makna dari sebuah gerakan teknik dasar dari materi yang akan disampaikan. Dalam tahap bertanya ini terjadi dua arah, maksudnya guru memberikan sebanyak- banyaknya kepada siswa untuk menanyakan apa saja yang telah siswa ketahui, dan dalam kesempatan yang sama guru harus menjawab sejelas mungkin sampai siswa memahaminya. Setelah semua pertanyaan yang dilontarkan oleh siswa sudah terjawab dengan jelas, maka giliran guru yang memberikan pertanyaan terkait apa yang telah diamati oleh siswa dengan tujuan guru mengetahui sejauh mana pengetahuan seorang siswa atau peserta didik.

3) Menalar

Menalar adalah memproses informasi yang sudah dikumpulkan baik terbatas dari hasil kegiatan mengumpulkan atau eksperimen maupun hasil dan kegiatan mengumpulkan informasi. Kegiatan ini dilakukan untuk menemukan keterkaitan satu informasi dengan informasi lainnya, menemukan pola dari keterkaitan informasi tersebut.

4) Mencoba

Tahap selanjutnya adalah mencoba dimana peserta didik diberi kesempatan untuk melakukan gerakan-gerakan berdasarkan hasil pengamatan tayangan dan pengamatan gambar yang tertera pada modul atau yang di demonstrasikan oleh guru dengan tujuan agar siswa atau peserta didik memiliki pengalaman dalam melakukan gerakan.

5) Mengkomunikasikan atau menyaji

Tahap ini merupakan tahap terakhir dimana siswa diberi kesempatan untuk mengkomunikasikan atau menyajikan kembali keterampilan gerak dari hasil latihan sebelumnya dengan tujuan dapat mengetahui sejauh mana kemampuan dalam melakukan gerakan yang benar.

Model pembelajaran pendidikan jasmani olahraga dan kesehatan yang digunakan dalam pembelajaran berbasis ilmiah pada masa saat ini yaitu model pembelajaran Problem Based Learning (PBL) Pembelajaran berdasarkan masalah (PBM). PBM adalah model pengajaran yang bercirikan adanya masalah nyata sebagai konteks untuk para siswa belajar berfikir kritis dan keterampilan memecahkan masalah serta memperoleh pengetahuan. Pembelajaran Berbasis Masalah (PBM) menyarankan kepada siswa untuk mencari sumber-sumber pengetahuan yang relevan dan pembelajaran ini memberikan tantangan kepada siswa untuk belajar secara mandiri. Dalam hal ini, siswa dalam membentuk suatu pengetahuan lebih sedikit mendapat bimbingan dari guru. 


\section{PENDIDIKAN JASMANI OLAHRGA DAN KESEHATAN}

Pendidikan jasmani merupakan suatu bidang kajian yang sangat luas dan memiliki titik perhatiannya pada peningkatan gerak manusia. Pendidikan jasmani dapat dikatakan juga sebagai proses dimana belajar itu melalui gerak. Belajar melalui gerak yang dimaksud adalah ketika siswa melakukan permainan beregu, selain melatih keterampilan peserta didik juga dapat belajar bekerjasama, percaya diri, saling tolong menolong, saling menghargai, sportif, jujur, disiplin dan memiliki mental yang kuat, sehingga proses belajar ini yang dapat menunjang terwujudnya watak peserta didik sekaligus dikatakan sebagai proses jangka panjang. Menurut Husdarta (2011) menyatakan pendidikan jasmani adalah proses pendidikan melalui aktivitas jasmani, permainan atau olahraga yang terpilih untuk mencapai tujuan pendidikan. Pendidikan jasmani sebagai komponen pendidikan secara keseluruhan telah disadari oleh masyarakat. Akan tetapi pelaksanaan pengajaran belum terlaksana secara efektif seperti apa yang diharapkan. Model pembelajaran pendidikan jasmani tidak harus terpusat pada guru, akan tetapi harus disesuaikan dengan perkembangan anak. Konsep dasar pendidikan jasmani dan model pengajarannya perlu dipahami. Pengertian pendidikan jasmani terkadang dikaburkan dengan konsep lain yaitu pengembangan organ-organ tubuh manusia dalam arti membentuk seorang siswa menjadi seorang atlet, padahal bukan itu yang menjadi tujuan dalam pendidikan, Pendidikan jasmani bukan hanya merupakan aktivitas pengembangan fisik, akan tetapi harus berada dalam konteks pendidikan secara umum yaitu belajar bergerak dan belajar melalui gerak, sehingga tertanamnya nilai-nilai karakter dalam diri siswa melalui seetiap gerakan yang dilakukan.

\section{KESIMPULAN}

Pada dasarnya kegiatan belajar mengajar adalah suatu proses interaksi atau hubungan timbal balik antara guru dan siswa dalam satuan pembelajaran. Guru atau pendidik sebagai salah satu komponen dalam proses belajar mengajar merupakan pemegang peran yang sangat penting. Guru atau pendidik bukan hanya sekedar penyampai materi saja, tetapi lebih dari itu yaitu sebagai sentral atau fasilitator. Oleh karena itu guru atau pendidik harus dapat membuat suatu pengajaran menjadi lebih efektif dan menarik, Pelaksanaan pembelajaran pendidikan jasmani olahraga dan Kesehatan pada saat ini sangatlah sulit dilaksanakan sebagaimana mestinya dilakukan seperti dalam keadaan normal. Tidak efektif jika hanya melalui tatap muka secara virtual saja, karena pendidikan jasmani merupakan pembelajaran yang lebih dominan dalam melakukan praktek secara langsung. Tentunya hal tersebut sangat sulit dilakukan pada masa saat ini. Selain sangat sulit dilakukan, adanya keterbatasan sarana yang dimiliki oleh masing-masing siswa atau peserta didik. Modul merupakan bahan ajar yang tepat digunakan pada masa saat ini, dengan sajian isi modul menggunakan model pembelajaran saintifik dan bisa digunakan di rumah secara mandiri tanpa adanya guru atau pendidik, walaupun saat ini masih menggunakan daring, akan tetapi penggunaan pembelajaran daring tidak dapat dilakukan secara maksimal. Tepatnya pembelajaran daring dimanfaatkan untuk menanyakan bagian yang kurang jelas dari apa yang sudah dipelajari di dalam modul, Selain itu modul juga dapat berdampingan dengan media audio visual dimana penyajian gambar yang belum lengkap di dalam modul bisa di tayangkan melalui audio visual tersebut., sehingga pembelajaran pada masa covid-19 ini bisa berjalan dengan baik.

\section{DAFTAR PUSTAKA}

UU Nomor 20 tahun 2003 tentang Sistem Pendidikan Nasional. https://referensi.elsam.or.id/2014/11/ uu-nomor-20-tahun-2003-tentangsistem- pendidikan-nasional/.Diakses tanggal 26 November 2020

Alwi. (2011). Kamus Besar Bahasa Indonesia. Jakarta: Balai Pustaka

Daryanto \& Karim, Syaiful. 2017. Pembelajaran Abad 21. Yogyakarta: Gava Medi

Depdiknas. (2008). Kompetensi Evaluasi Pendidikan.Jakarta: Depdiknas 
JUPE: Jurnal Pendidikan Mandala

http://ejournal.mandalanursa.org/index.php/JUPE/index
Vol. 5. No. 6 Desember 2020

p-ISSN: 2548-5555 e-ISSN: 2656-6745

Direktorat Jenderal Manajemen Pendidikan

Dasar dan Menengah Departemen

Pendidikan Nasional. Tahun (2008) tentang

Teknik Penyusunan Modul

Husdarta. (2011). Manajemen Pendidikan

Jasmani. Bandung:Alfabeta

Majid. (2014). Implementasi Kurikulum 2013.

Bandung: Interes Media

Prastowo, A. (2012). Panduan Kreatif Membuat Bahan Ajar Inovatif.

Yogyakarta: Diva Press

Rusman, dkk (2011) Pembelajaran Berbasis

Teknologi Informasi dan Komunikasi

Mengembangkan Profesionalisme Guru.

Jakarta:Rajawali Pers. PT. Raja

Grafindo Persada

Sukiman. (2011). Pengembangan Media Pembelajaran. Yogyakarta: Pustaka Insan Madani 